\title{
PERSEPSI PERAWAT SEBAGAI EDUKATOR BERHUBUNGAN DENGAN IMPLEMENTASI DISCHARGE PLANNING
}

\author{
Fransiska Denata Rangga ${ }^{1}$, Sandra Vasquien ${ }^{2)}$, \\ Martina Pakpahan ${ }^{3 *}$, Martha Octaria ${ }^{3)}$ \\ ${ }^{1)}$ Rumah Sakit Siloam Kupang, Jalan R.W. Monginsidi, Kupang, NTT \\ ${ }^{2)}$ Rumah Sakit Siloam, Jalan Sunset Road, Kuta, Bali \\ ${ }^{3)}$ Fakultas Keperawatan,Universitas Pelita Harapan, Jalan Jenderal Sudirman, \\ Tangerang, Banten
}

e-mail: martina.pakpahan@uph.edu; martha.octaria@uph.edu

\begin{abstract}
ABSTRAK
Perawat sebagai edukator berperan penting dalam implementasi discharge planning (perencanaan pulang). Implementasi Discharge planning yang tidak optimal dapat meningkatkan lama rawat, angka rawat ulang, dan pembiayaan. Tujuan penelitian untuk mengidentifikasi hubungan persepsi perawat sebagai edukator terhadap implementasi Discharge Planning oleh perawat. Penelitian ini adalah penelitian kuantitatif dengan desain cross sectional. Teknik pengambilan sampel adalah total sampling dengan jumlah responden adalah 43 orang perawat di ruang rawat inap di satu Rumah Sakit Swasta Indonesia Bagian Tengah. Pengumpulan data dilakukan dengan menggunakan kuesioner dan melakukan observasi. Analisa data dalam bentuk univariat dan bivariat. Analisis bivariat menggunakan uji Chi Square. Pada analisis univariat didapatkan sebesar $40(93,02 \%)$ responden memiliki persepsi negatif dan sebesar $36(83,72 \%)$ responden tidak melaksanakan discharge planning sesuai standar prosedur operasional. Pada analisis bivariat didapatkan adanya hubungan antara persepsi perawat sebagai edukator dengan implementasi discharge planning oleh perawat di Rumah Sakit Swasta Indonesia Bagian Tengah ( $p$ value 0,001). Rumah sakit dapat membangun persepsi positif perawat sebagai edukator melalui pelatihan dan pendampingan dalam melaksanakan discharge planning sesuai standar. Penelitian selanjutnya dapat meneliti hubungan variabel lainnya terhadap implementasi discharge planning.
\end{abstract}

Kata kunci: Discharge Planning; Edukator; Implementasi; Perawat; Persepsi

\begin{abstract}
The nurses as an educator becomes an important part in the implementation of discharge planning. The implementation of the optimal Discharge planning can increase the length of stay in hospital, readmission, and financing. The aim of the study to identify the correlation between nurse's perception as an educator with the implementation of Discharge Planning by nurses. This research was a quantitative study with cross sectional design. Sampling technique used the total sampling with 43 nurses in the inpatient room in one central Indonesian private hospital as a respondents. Data collection was carried out using questionnaires and observation. Data analysis in the form of univariate and Bivariat. Bivariate analysis using Chi Square test. The univariate analysis was found by $40(93.02 \%)$ Respondents had negative perception and to 36 (83.72\%) The respondent did not implement discharge planning according to standard operating procedures. Bivariat analysis found the correlation between the perception of nurses as an educator with the implementation of discharge planning by nurses ( $p$ value 0.001). The hospitals can develop a positive perception of nurses as an educator through training and mentoring in carrying out standard discharge planning. Further research can examine the correlation of other variables on the implementation of discharge planning.
\end{abstract}

Keywords: Discharge Planning; Educator; Implementation; Nurses; Perception

Jurnal Kesehatan Holistic/ Volume 4/ Nomor 2/Juli 2020

(ISSN: 2548-1843, EISSN: 2621-8704) 


\section{PENDAHULUAN}

Peran perawat dalam pelayanan keperawatan salah satunya sebagai edukator. Perawat sebagai garda terdepan pemberi pelayanan kesehatan di Rumah Sakit dituntut sanggup berperan sebagai edukator. Perawat sebagai edukator menolong meningkatkan kesehatan pasien dengan membagikan pengetahuan terkait perawatan serta tindakan medis yang diterima sehingga pasien ataupun keluarga sanggup membuat keputusan serta berupaya untuk mengoptimalkan kemampuan hidup secara mandiri (Pertiwati, 2016).

Sebagai edukator perawat menjadi bagian dalam discharge planning. Discharge planning merupakan pendekatan interdisipliner untuk perawatan berkelanjutan serta proses yang mencakup identifikasi, penilaian, penetapan tujuan, perencanaan, implementasi, koordinasi, dan evaluasi (Jung et al, 2012).

Jung et al (2012) menambahkan bahwa Discharge planning yang efektif menunjang perawatan kesehatan berkelanjutan, sebagai hubungan kritis antara perawatan yang diterima pasien di rumah sakit dan perawatan setelah pulang yang diberikan di masyarakat.

Beberapa penelitian menemukan discharge planning yang efektif sangat berarti dalam meningkatkan kesehatan pasien, mengurangi lama rawat dan rawat ulang. Discharge planning juga berdampak kepada angka kematian, health outcomes dan pembiayaan (Shepperd et al, 2010). Maka karena itu penting untuk dilakukannya discharge planning sesuai standar dalam hal ini mengacu kepada standar prosedur operasional (SPO) rumah sakit. Implementasi discharge planning yang terstruktur dan disesuaikan dengan pasien secara individu teruji mampu menurunkan lama rawat di rumah sakit dan angka readmission terutama pada lanjut usia (Shepperd et al, 2010).

Soebagiyo dkk (2019) menjelaskan bahwa Discharge Planning tidak hanya rumit tetapi juga merupakan kegiatan jangka panjang, mulai dari ketika pasien dirawat di rumah sakit sampai mereka diizinkan untuk pulang. Secara faktual, tidak dapat 
dipungkiri bahwa implementasi discharge planning yang efektif akan memberikan manfaat bagi pasien, keluarga pasien dan para profesional dalam lingkungan perawatan kesehatan. Komunikasi yang efektif, keberlanjutan staf yang merawat dan tersedianya waktu yang cukup turut mempengaruhi kualitas discharge planning (Soebagiyo dkk, 2019).

Graham et al, (2013) menginformasikan bahwa di Australia hanya $23 \%$ perawat tidak melaksanakan discharge planning. Hal serupa di Inggris bagian Barat Daya diinformasikan bahwa $34 \%$ perawat tidak melaksanakan discharge planning (Morris et al, 2012). Sebaliknya di Indonesia, sebanyak $61 \%$ perawat di Yogyakarta tidak melaksanakan discharge planning dan $54 \%$ perawat di Bandung tidak melaksanakan discharge planning (Zuhra, 2016).

Berdasarkan observasi peneliti pada tanggal 16 Desember tahun 2017 sampai dengan tanggal 01 Maret tahun 2018 di satu Rumah Sakit Swasta Indonesia Bagian Tengah, discharge planning (perencanaan pulang) tidak $100 \%$ dilakukan sesuai SOP (Standar Oprerasional Prosedur). Perawat masih berfokus pada informasi kontrol ulang dan informasi mengenai obat yang dikomsumsi di rumah. Hal ini juga di dukung olah data medical record yang di dapatkan dari Rumah Sakit Swasta Indonesia Bagian Tengah pada tanggal 19 Maret 2018, yang menunjukkan bahwa pada tahun 2017 terdapat 14 orang pasien post rawat inap melakukan readmission atau datang kembali ke Rumah Sakit untuk dilakukan perawatan kembali dalam waktu dua minggu keluar dari Rumah Sakit.

Hasil penelusuran literatur pada jurnal dan pangkalan data, sangat sedikit ditemukan publikasi penelitian mengenai faktor yang berhubungan dengan implementasi discharge planning dari sisi perawat. Padahal perawat memiliki peran yang penting sebagai edukator dalam discharge planning. Penelitian yang telah dilakukan dan dipublikasikan lebih banyak berupa penilaian, persepsi ataupun pengetahuan pasien dan keluarga terhadap pelaksanaan discharge planning yang dilakukan perawat. Penelitian ini berbeda sebab 
menggali dari sisi perawat sebagai pelaksana discharge planning secara khusus dalam aspek persepsi perawat. Maka peneliti tertarik untuk meneliti mengenai "Hubungan Persepsi Perawat Sebagai Edukator dengan Implementasi Discharge Planning Di Satu Rumah Sakit Swasta Indonesia Bagian Tengah". Pada penelitian ini hipotesa yang dipilih oleh peneliti adalah Ha yaitu adanya hubungan persepsi perawat sebagai edukator terhadap implementasi discharge planning oleh perawat.

\section{METODE}

Penelitian dilaksanakan pada bulan Juni-Juli tahun 2018 di Satu Rumah Sakit Swasta Indonesia Bagian Tengah. Rumah Sakit meminta identitas dirahasiakan untuk publikasi hasil penelitian. Penelitian ini adalah penelitian kuantitatif dengan desain cross sectional. Cross sectional yaitu desain penelitian dimana pengukuran atau pengamatan terhadap fenomenafenomena yang diteliti dilakukan pada saat bersamaan atau sekali waktu dan kemudian diidentifikasi hubungan dari fenomena-fenomena tersebut (Pollit and Beck, 2010).
Penelitian ini menggunakan total sampling, dengan jumlah responden 43 perawat di ruang rawat inap satu, dua dan tiga. Penelitian telah lulus etik dari tim etik Fakultas Keperawatan Universitas Pelita Harapan. Penelitian ini dilakukan dengan menggunakan lima prinsip etika (Polit \& Beck, 2010), yaitu: 1) Beneficience, 2) Respect for Human Dignity, 3) Justice, 4) Confidentiality, and 5) Infromed Consent.

Penelitian ini memiliki dua variabel untuk diteliti yaitu persepsi perawat sebagai variabel bebas dan implementasi discharge planning sebagai variabel terikat. Variable persepsi perawat diukur dengan menggunakan kuesioner. Kuesioner terdiri dari 20 pertanyaan dengan pilihan jawaban dalam skala likert. Kuesioner dikembangkan sendiri oleh peneliti dengan melihat kepada teori terkait dan penelitian sebelumnya yang relevan. Sebelum digunakan, kuesioner telah lulus uji validitas dan reliabilitas. Nilai $\mathrm{r}$ hitung 20 pertanyaan tersebut lebih besar dari nilai r tabel dengan Cronbach alpha sebesar 0,783 . 
Variabel implementasi discharge

planning diukur dengan melakukan observasi terhadap perawat saat melakukan discharge planning. Lembar observasi dikembangkan dari standar prosedur operasional rumah sakit dalam melaksanakan discharge planning. Peneliti melakukan satu kali observasi terhadap responden. Peneliti mendiskusikan item observasi yang terdapat pada lembar observasi dalam menyamakan persepsi. Selain itu peneliti juga melakukan observasi bersama kepada responden pertama. Lalu mendiskusikan hasil observasi yang didapat dari kedua peneliti untuk semakin menyamakan persepsi. Setelah peneliti menyamakan persepsi maka selanjutnya masing-masing peneliti melakukan observasi terpisah.

Peneliti membagi jumlah responden yang akan diobservasi. Observasi terpisah ini juga dimaksudkan untuk meminimalkan resiko responden mengetahui bila sedang diobservasi.

Peneliti mengamati responden dalam melakukan discharge planning sejak pasien masuk ruangan sampai dengan pasien pulang dari ruangan.
Pengolahan data dilakukan dengan software statistik. Proses pengolahan data yang dilakukan berupa editing, coding, processing dan cleaning. Analisa data berupa adalah analisis univariat dan bivariat. Uji chi square digunakan dalam analisis bivariat sebab kedua variable yang diteliti merupakan variabel kategorik.

\section{HASIL}

Hasil analisis univariat terhadap karakteristik responden didapatkan hasil pada tabel 1 .

Tabel 1

Distribusi Berdasarkan Karakteristik Responden Di Satu Rumah Sakit Swasta Indonesia Bagian Tengah $(n=43)$.

\begin{tabular}{ccc}
\hline Variabel & $\begin{array}{c}\text { Frekuensi } \\
(\mathrm{n})\end{array}$ & $\begin{array}{c}\text { Persentase } \\
(\%)\end{array}$ \\
\hline Tingkat & & \\
pendididikan & & \\
- D3 & 18 & 41,86 \\
- S1 & 25 & 58,14 \\
Total & 43 & 100 \\
\hline Lama Kerja & & \\
-<1 tahun & 8 & 18,6 \\
-1 tahun & 5 & 11,6 \\
-2 tahun & 9 & 20,9 \\
-3 tahun & 8 & 18,6 \\
-4 tahun & 1 & 2,32 \\
-5 tahun & 12 & 27,98 \\
\hline
\end{tabular}

Berdasarkan tabel 1 diketahui data responden dengan tingkat pendidikan S1 sebanyak $25(58,14 \%)$ responden dan D3 sebanyak $18 \quad(41,86 \%)$ responden. Berdasarkan lama kerja 
diketahui bahwa responden dengan lama kerja lima tahun sebanyak 12 $(27,98 \%)$ responden, lama kerja empat tahun sebanyak $1 \quad(2,32 \%)$ responden, lama kerja tiga tahun sebanyak $8(18,6 \%)$ responden, lama kerja dua tahun sebanyak $9(20,9 \%)$ responden, lama kerja satu tahun sebanyak $5(11,6 \%)$ responden, dan lama kerja kurang dari tahun sebanyak $8(18,6 \%)$ responden.

Hasil analisis univariat terkait persepsi perawat sebagai edukator didapatkan hasil sebagai berikut:

\section{Tabel 2}

Distribusi Gambaran Persepsi Perawat Sebagai Edukator Di Satu Rumah Sakit Swasta Indonesia Bagian Tengah $(n=43)$.

\begin{tabular}{ccc}
\hline Persepsi & $\begin{array}{c}\text { Frekuens } \\
\mathrm{i}(\mathrm{n})\end{array}$ & $\begin{array}{c}\text { Persentas } \\
\mathrm{e}(\%)\end{array}$ \\
\hline -Positif (> mean) & 3 & 6,98 \\
-Negatif ( $\leq$ mean) & 40 & 93,02 \\
Total & 43 & 100 \\
\hline
\end{tabular}

Pada tabel 2 diketahui sebesar 40 $(93,02 \%)$ responden memiliki persepsi negatif sebagai edukator dan hanya sebesar $3(6,98 \%)$ responden yang memiliki persepsi positif sebagai edukator.

Pada tabel 3 diketahui bahwa sebanyak $36 \quad(83,72 \%)$ responden melaksanakan discharge planning tidak sesuai dengan SPO. Perawat yang melaksanakan discharge planning sesuai dengan SPO 100\% sesuai dengan SOP sebanyak 7 $(16,28 \%)$ responden.

\section{Tabel 3}

Distribusi Implementasi Discharge Planning Di Satu Rumah Sakit Swasta Indonesia Bagian Tengah $(n=43)$.

\begin{tabular}{lcc}
\hline Implementasi & $\begin{array}{c}\text { Frekuensi } \\
(\mathrm{n})\end{array}$ & $\begin{array}{c}\text { Persentase } \\
(\%)\end{array}$ \\
\hline -Sesuai SPO & 7 & 16,28 \\
-Tidak sesuai & 36 & 83,7 \\
$\quad$ SPO & & \\
Total & 43 & 100 \\
\hline
\end{tabular}

Hasil analisa bivariat terhadap hubungan persepsi perawat sebagai edukator dengan implementasi discharge planning didapatkan data sebagai berikut:

Tabel 4

Analisis Hubungan Persepsi Perawat Sebagai Edukator dengan Implementasi Discharge Planning di Satu Rumah Sakit Swasta Indonesia Bagian Tengah $(n=43)$

\begin{tabular}{clll}
\hline Persepsi & \multicolumn{2}{c}{$\begin{array}{c}\text { Implementasi } \\
\text { Discharge } \\
\text { planning }\end{array}$} & Total \\
\cline { 2 - 3 } & $\begin{array}{c}\text { Tidak } \\
\text { sesuai } \\
\text { SPO }\end{array}$ & $\begin{array}{c}\text { Sesuai } \\
\text { SPO }\end{array}$ \\
\hline Positif & 0 & 4 & 4 \\
& $(0 \%)$ & $(10 \%)$ & $(100 \%)$ \\
Negatif & 36 & 3 & 39 \\
& $(90 \%)$ & $(100 \%)$ & $(100 \%)$ \\
Jumlah & 36 & 7 & 43 \\
& $(83,7 \%)$ & $(16,3 \%)$ & $(100 \%)$ \\
\hline
\end{tabular}

$* \overline{p 0,001}$

Pada tabel 4, diketahui hasil analisis bivariat pada uji chi square 
didapatkan nilai $p 0,001$. Maka dapat disimpulkan adanya hubungan bermakna antara persepsi perawat sebagai edukator dengan implementasi discharge planning sesuai SPO. Dengan kata lain Ho ditolak.

\section{PEMBAHASAN}

Peneliti menemukan sebagian besar responden memiliki tingkat pendidikan akhir strata satu (S1) dan sebagian besar dari responden memiliki pengalaman kerja $>5$ tahun. Hal ini berlawanan terhadap data responden yang melakukan discharge planning sesuai SPO hanya sebesar 16,28\%. Maka dapat dismpulkan bahwa tingkat pendidikan dan lama kerja tidak berhubungan dengan implementasi perawat dalam melakukan discharge planning sesuai SPO.

Hasil penelitian tersebut tidak sesuai dengan teori yang dipaparkan oleh Ismainar (2015) yang menyatakan faktor yang mempengaruhi persepsi terdiri dari (1) Pelaku persepsi, diantaranya pengalaman dan harapan. (2) faktor pada target, diantaranya sesuatu yang baru, gerakan, suara, latar belakang. (3) faktor dalam situasi, diantaranya waktu, keadaan kerja, keadaan sosial.

Ismainar (2015) menjelaskan bahwa seseorang dalam melakukan suatu tindakan atas pilihan ataupun keputusan yang diambil sebagian besar dipengaruhi oleh persepsi. Pada akhirnya akan terlihat bahwa tindakan yang dilakukan tersebut berhubungan dengan persepsi seseorang individu (Ismainar, 2015). Maka dalam hal ini implementasi yang dilakukan perawat dipengaruhi oleh persepsinya mengenai tindakan tersebut.

Hasil penelitian didapatkan bahwa sebagian besar perawat memiliki persepsi negatif sebagai edukator yaitu sebesar 93,02\%. Maka dapat disimpulkan bahwa mayoritas perawat menganggap perannya sebagai edukator dalam discharge planning tidaklah penting. Hal ini sangat berlawanan dengan tujuan edukasi discharge planning yang diberikan perawat untuk menambah pemahaman dan keterampilan pasien untuk memenuhi kebutuhan perawatan berkelanjutan setelah pulang (Perry \& Potter, 2013). Jelas 
tidak mungkin seseorang perawat dapat melakukan perannya sebagai edukator dengan baik bila memiliki persepsi negatif terhadap perannya tersebut. Padahal edukasi kesehatan diberikan kepada pasien sesuai dengan kebutuhannya baik selama masa perawatan di Rumah Sakit maupun setelah pulang ke rumah untuk mempersingkat masa perawatan, mempercepat proses penyembuhan, mengurangi risiko komplikasi penyakit dan angka rawat ulang (readmission).

Hasil penelitian senada dengan hasil penelitian Safrina dan Putra (2016) tentang "Persepsi Perawat Pelaksana Terhadap Pentingnya Discharge Planning di RSUDZA Banda Aceh" didapatkan bahwa $34,4 \%$ perawat pelaksana mempersepsikan pelaksanaan discharge planning sebagai hal penting dilakukan, sedangkan $\quad 65,6 \%$ mempersepsikan sebaliknya.

Didapatkan bahwa $36 \quad(83.72 \%)$ responden melakukan discharge planning tidak sesuai dengan standar prosedur operasional rumah sakit. Peneliti menemukan sebagian besar responden, melaksanakan discharge planning hanya ketika pasien akan pulang dan seringkali berfokus pada informasi obat dan jadwal kontrol saja. Sangat jarang ditemukan perawat menjelaskan mengenai kondisi kesehatan pasien dan hal-hal penting diketahui baik mengenai hal yang harus dilakukan ataupun dihindari juga keterampilan untuk dilakukan selama perawatan di rumah.

Hasil penelitian ini sesuai dengan penelitian Suryadi (2013) mengenai "Hubungan Peran Edukator Perawat dalam Discharge Planning dengan Tingkat Kepatuhan Pasien Rawat Inap Untuk Kontrol di Rumah Sakit Paru Kabupaten Jember" yang mendapatkan bahwa peran perawat sebagai edukator dalam implementasi discharge planning tidak dilaksanakan $100 \%$, dimana Perawat hanya mengacu pada lembar Cheklist discharge planning yang digunakan oleh Rumah Sakit dan tidak memberikan pendidikan secara detail sesuai kebutuhan pasien dan SPO yang berlaku. 
Hal ini berbeda dari konsep Discharge planning yang mencakup semua perawatan yang diberikan kepada pasien mulai dari saat masuk, selama dirawat di rumah sakit, sampai saat pemulangan (Nursalam dkk, 2017). Program discharge planning seharusnya merupakan program penyampaian informasi ataupun pendidikan kesehatan kepada pasien berupa; nutrisi, aktifitas, pengobatan serta instruksi khusus mengenai tanda dan gejala penyakit pasien yang perlu diperhatikan (Perry \& Potter, 2013). Fokus discharge planning dapat diperluas sebagai informasi untuk meningkatkan pemahaman pasien, motivasi dan keterampilan untuk manajemen diri di rumah (Flink and Ekstedt, 2017). Studi lainnya menyimpulkan bahwa discharge planning memiliki efek untuk meningkatkan kepatuhan pasien terhadap terapi (obat oral dan injeksi, nutrisi dan aktivitas) (Nursalam dkk, 2017). Penelitian lain menyebutkan bahwa pasien yang menerima discharge planning secara terstruktur sejak masuk rawat terbukti memiliki status personal, pengetahuan, kemampuan koping dan dukungan yang lebih tinggi dibandingkan pasien yang tidak menerima discharge planning terstruktur atau sekedarnya (Wahyuni dkk, 2012).

Hasil penelitian menemukan adanya hubungan antara persepsi perawat sebagai edukator dengan implementasi discharge planning. Pesepsi mayoritas perawat yang negatif terhadap perannya sebagai edukator tentu mempengaruhinya dalam mengimplementasikan discharge planning sesuai SPO. Persepsi perawat yang negatif tersebut terlihat dari hasil observasi yang menemukan sebagian besar responden dalam pelaksanaan discharge planning hanya berfokus pada informasi obat dan jadwal kontrol, sangat jarang perawat menjelaskan mengenai perkembangan kondisi pasien, perawatan dirumah baik yang harus dilakukan, yang perlu dihindari atau diwaspadai. Perawat menganggap pemberian edukasi komprehensif kepada pasien yang akan meninggalkan Rumah Sakit kurang penting untuk dilakukan.

Ismainar (2015) menjelaskan bahwa seseorang dalam melakukan suatu tindakan atas pilihan yang diambil 
sebagian besar dipengaruhi oleh persepsinya, dimana persepsi ini mempunyai pengaruh besar pada hasil akhir. Maka seorang perawat dalam melakukan tindakan keperawatan tentu dipengaruhi oleh persepsinya terhadap tindakan tersebut.

Padahal seharusnya edukasi kesehatan bertujuan meningkatkan pengetahuan dan keterampilan pasien dan keluarga dalam memenuhi kebutuhan perawatan berkelanjutan (Perry \& Potter, 2013). Discharge planning dikatakan berhasil bila terjadi suatu proses koordinasi terpusat dari berbagai disiplin ilmu dalam memberikan kepastian bagi pasien dengan suatu rencana perawatan berkelanjutan setelah pulang dari Rumah Sakit (Perry \& Potter, 2013).

Beberapa penelitian menemukan bahwa Discharge planning yang dilaksanakan tidak sesuai SPO akan berdampak bagi pasien. Dampak tersebut yaitu; meningkatnya lama rawat, kejadian rawat ulang (readmission), resiko komplikasi, prognosis kesembuhan pasien dan pembiayaan. Hal ini tentu merugikan pasien beserta keluarga dan juga Rumah Sakit.

Readmission menjadi salah satu indikator mutu pelayanan di Rumah Sakit, bahkan peningkatan perawatan terhadap pasien dan penurunan readmission dalam kurun waktu kurang dari 30 hari amenjadi target nasional bagi Rumah Sakit (Philips et al, 2004 dalam Rahmi, 2011). Data medical record yang di dapatkan dari Rumah Sakit Swasta Indonesia Bagian Tengah pada tanggal 19 Maret 2018 menunjukkan bahwa pada tahun 2017 terdapat 14 orang pasien post rawat inap melakukan readmission atau datang kembali ke Rumah Sakit untuk dilakukan perawatan kembali dalam waktu dua minggu keluar dari Rumah Sakit.

Hambatan yang paling umum dalam discharge planning yang teridentifikasi adalah keterbatasan waktu dan faktor dari pasien (Graham et al, 2013). Hal lainnya yang ditemukan adalah kontradiksi perawat yang memahami pentingnya perencanaan pemulangan, namun tidak melakukannya sesuai aturan discharge planing yang ada di rumah 
sakit (Graham et al, 2013). Perawat membutuhkan motivasi dan dukungan dalam melaksanakan discharge planning sesuai SPO. Pelaksanaan discharge planning penting sebagai transisi pasien yang aman dari satu pengaturan perawatan ke area selanjutnya. Maka persepsi positif dan kepatuhan perawat dalam mengimplementasikan discharge planning sesuai SPO di ruang perawatan mutlak diperlukan.

\section{KESIMPULAN}

Hasil penelitian didapatkan bahwa bahwa $40 \quad(93,02 \%)$ responden memiliki persepsi negatif terhadap peran sebagai edukator dalam implementasi discharge planning dan $36(83.72 \%)$ responden tidak melakukan discharge planning sesuai dengan standar prosedur operasional rumah sakit. Hasil penelitian juga menunjukkan adanya hubungan antara persepsi perawat sebagai edukator dengan implementasi discharge planning oleh perawat $\mathrm{di}$ Satu Rumah Sakit Swasta Indonesia bagian Tengah.

\section{SARAN}

Rumah sakit dapat membangun persepsi positif perawat sebagai edukator melalui pelatihan, pendampingan bahkan reward dalam melaksanakan discharge planning sesuai standar prosedur operasional. Penelitian selanjutnya dapat meneliti hubungan variabel lainnya seperti pengetahuan, sikap, motivasi terhadap implementasi discharge planning sesuai standar prosedur operasional oleh perawat.

\section{UCAPAN TERIMAKASIH}

Fakultas Keperawatan dan LPPM Universitas Pelita Harapan dalam memotivasi penulis melakukan publikasi hasil penelitian.

\section{DAFTAR PUSTAKA}

Flink, M., \& Ekstedt, M. (2017). Planning for the Discharge, not for Patient Self-Management at Home-An Observational and Interview Study of Hospital Discharge. International journal of integrated care,17(6). http://doi.org/10.5334/ijic.3003 
Graham, J., Gallagher, R., \& Bothe, J. (2013). Nurses' discharge planning and risk assessment: behaviours, understanding and barriers. Journal of clinical nursing, 22(15-16), 2338-2346. https://doi.org/10.1111/jocn.1217 9

Ismainar, H. (2018). Manajemen unit kerja: untuk perekam medis dan informatika kesehatan ilmu kesehatan masyarakat keperawatan dan kebidanan. Deepublish. Retrieve from : https://scholar.google.com/schola $\mathrm{r} ? \mathrm{hl}=\mathrm{en} \&$ as_sdt=0\%2C5\&q=Man ajemen+Unit+Kerja\%3A+Untuk +Perekam+Medis+dan+Informati ka+Kesehatan+Ilmu+Kesehatan+ Masyarakat+Keperawatan+dan+ Kebidanan.\&btnG=

Jung Lin, Chin., Jung Cheng, Shih., Chuan Shih, Shou., Hsin Chu, Cheng., Tjung, Jin-jin. (2012) Review Article : Discharge Planning. International Journal of Gerontology. Volume 6, Issue 4, December 2012, Pages 237240.

Elsevier. https://doi.org/10.1016/j.ijge.201 2.05.001

Morris, J. Winfield, L. Young, K. (2012). Registered Nurses' Perception of The Discharge Planning Process For Adult Patients in an Hospital. Journal of Nursing Education and Practice, Vol 2(1), 28-39. http://dx.doi.org/10.5430/jnep.v2 n1p28

Nursalam, N., Sumiatun, S., \& Musrini, A. (2017). Discharge Planning Increase Therapy Obedient of Patients. Jurnal Ners, 3(2), 184-188. https://ejournal.unair.ac.id/JNERS/article /view/5003. http://dx.doi.org/10.20473/jn.v3i 2.5003

Pertiwati, E. Rizany, I. (2016). Peran Educator Perawat Dengan Pelaksanaan Discharge Planning Pada Pasien Di Ruang Tulip 1C RSUD Ulin Banjarmasin. Dunia Keperawatan, 4(2), 82-87. http://dx.doi.org/10.20527/dk.v4i 2.2509 
Perry, A. G., Potter, P. A., \& Ostendorf, W. (2013). Clinical nursing skills and techniques. Elsevier Health Sciences.

Polit, D. F., \& Beck, C. T. (2010). Essentials of nursing research $7^{e d}$. Lippincott Williams \& Wilkins.

Rahmi, U. (2011). Pengaruh discharge planning terstruktur terhadap kualitas hidup pasien stroke iskemik di RSUD Al-Ihsan dan RS Al-Islam Bandung. Universitas

Indonesia, 2. Retrieve from :

http://lib.ui.ac.id/file?file=digital/ 20282707 -

T\%20Upik\%20Rahmi.pdf

Safrina, N., dan Putra, A. (2016). Persepsi Perawat Pelaksana Terhadap Pentingnya Discharge Plnanning RSUDZA Banda Aceh. Jurnal Ilmiah Mahasiswa, 1(1),1-9. Retrieve from : http://www.jim.unsyiah.ac.id/FK ep/article/viewFile/1597/1879

Shepperd, S., Lannin, N. A., Clemson, L. M., McCluskey, A., Cameron, I. D., \& Barras, S. L.
(2013). Discharge planning from hospital to home. Cochrane database of systematic reviews. Cochrane Library. https://doi.org/10.1002/14651858 .CD000313.pub4

Soebagiyo, H., Beni, K. N., \& Fibriola, T. N. (2019). The Analysis of the Influencing Factors related to the Effectiveness of Discharge Planning Implementation in Hospitals: A Systematic Review. Jurnal Ners, 14(3 (si)), 217-220.

http://dx.doi.org/10.20473/jn.v14 i3.17103

Suryadi, R. F. (2013). Hubungan peran educator perawat dalam discharge planning dengan tingkat kepatuhan pasien rawat inap untuk kontrol di Rumah Sakit Paru Kabupaten Jember. Retrieve from https://repository.unej.ac.id/bitstr eam/handle/123456789/3285/Riz a\%20Firman\%20Suryadi\%20$\% 20092310101027 . p d f$ sequence $=1$

Wahyuni, A., Nurrachmah, E., \& Gayatri, D. (2012). Kesiapan 
pulang pasien penyakit jantung koroner melalui penerapan discharge planning. Jurnal keperawatan indonesia, 15(3), 151-158.

DOI: https://doi.org/10.7454/jki.v15i3. 3
Zuhra, P. (2016). Gambaran Pelaksanaan Discharge Planning Pasien Pasca operasi Apendiktomi $\quad D i \quad R S \quad P K U$ Muhammadiyah Gamping Yogyakarta. Universitas Muhammadiyah Yogyakarta, 5000. 